\title{
The 3-D Animated Codescape: Imperfection and Digital Labor Zones in Wall-E (2008) and Wreck-It Ralph (2012)
}

\author{
Keith B Wagner and In-gyoo Jang
}

Hongik University, Seoul, South Korea

\begin{abstract}
Live-action film and video games share a presence and convergence in each media's visuality and narrative storytelling; this is especially apparent over the last four decades - from Tron (1982) to Run Lola Run (1998) to The Beach (2000) and now 'machinima' as new computational genre cinema via Minecraft (2014). To complicate matters, only recently are cinema and video games now tropes in 3-D computer animation, with films such as Wall-E (Andrew Stanton, 2008) and Wreck-It Ralph (Rich Moore, 2012) absorbing these cultural relations. In this article, the authors explicate on two interwoven yet separable themes in the Walt Disney/Pixar films. First, they theorize aspects of the 'imperfect aesthetic' as connected to an audience and industry's desire to aesthetically 'deskill' - as explained in John Roberts's article 'Art after deskilling' (2010) - the image of its characters, in the process making the characters more vulnerable and thus more endearing. This imperfect aesthetic is typically associated with avant-garde animation or animated shorts, yet to link imperfection to 3-D computer animation illustrates a new visual tendency since the 2000s. Second, they draw on the scholarship of Maurizio Lazzarato to relate immaterial labor to what each character does in their animated worlds, what they call 'digital labor zones': the Wall-E robot is prone to affective labor while in Wreck-It Ralph, Ralph, the goofy villain, begins to question the reasons for his rampaging behavior and the labor behind such actions.
\end{abstract}

\section{Keywords}

3-D computer animation, codescape, deskilling, digital labor zones, film and video games, imperfect aesthetic, John Roberts, Wall-E, Wreck-It Ralph

Wall-E (Andrew Stanton, 2008) and Wreck-It Ralph (Rich Moore, 2012) continue the 3-D computer-animated film cycle ${ }^{1}$ produced since the new millennium, yet with surprising new subtexts that speak to popular US culture and revive aesthetic discourses. These 3-D computer renderings in Wall-E and Wreck-It Ralph signify the further evolution of animated films that have begun to borrow from other mediums - such as live-action film and video games - no longer limited to cartoons, short stories or popular literature and folklore. What cinema and gaming now find in common with 3-D computer animation, amongst other things, is a platform for cultural expression that now overlaps and enmeshes itself in all three forms of visual media. Today we find a recogniz- able genealogy of video games - from Donkey Kong to Halo, Atari to Sega to Xbox, to Hollywood musicals (Hello, Dolly!) and action films (Aliens) - all incorporated into 3D computer-animated films with levels of playfulness and sophistication. Yet this animation's appropriation is far more than just empty pastiche so often linked to postmodern creativity. In some ways, it falls outside what Fredric Jameson (1991: 115) condemns as 'a world in which stylistic innovation is no longer possible, all that is left is to imitate dead styles, to speak through the masks and with the voices of the styles in the imaginary museum.'

The epoch that Jameson is referring to is primarily the 1980s and 1990s, a period right before the so-called rise of what Orit Halpern (2015) calls the latter phase of a 'beautiful date' of a 
com- putational kind. Her theorization about the 'cartography of this complicated terrain' in the design of data is illuminating (p. 21). How the new technical condition of digital processing in the last 20 years references itself in communication, science, and design, is now something cultivated in 3-D computer animation, too. Here data or the computational nature of digital images are also literal- ized in animation as the description of 'rendering practices by machines, scientific instrument and numeric measures', writes Halpern (p. 21). From IBM and their first computers in the 1950s to the most wired city on earth in the 2010s - Songdo, in South Korea Halpern goes some way to articu- late and historicize data display and considers how such visualization is observable. In moving this visualization of data in another direction, this article implies the relationship between data in the coding of 3-D computer animation and its cultural significance to audiences in the US; here we see it as both motif and reference to media's remediation and self-referentiality. With its grid-like infra- structure of animation design in computing as well as its metaphoric communication of cultural data, such authorship is perceivable with those 'algorithmic actions' (p. 46) that might be thought of as a codescape.

Our formulation of an animated codescape adheres to the augmented worlds of digital cinema, gaming and now 3-D computer animation culture in their porous interconnectivity as media; each becomes a creative space of immersion and thus moves beyond a simple imitation of styles as each is its own hypertext of sorts. With the codification of programming now firmly entrenched in ani- mation, data sorting and binary language have enabled the systematic organization of size, pixela- tion, color balance and shading of digital animation which have come to form a codescape of 3-D scale and ratio, spatial movement and volumetric shaping. It is here that the animated codescape ought to be viewed not only as complex program design but also to be interpreted as a patchwork of cultural references to our computational recent past. Indeed, the closer we get to new visions of animation, the more this newer codified visuality reminds us of animation's history: its mechanical imprecision and the laborious rotoscoping features that have transformed into painstaking render- ings and modeling in digital animation processes today.

In order to bypass Jameson's well-heeded warning and Halpern's acute notion of making com- puter language visible, we deploy the 'imperfect aesthetic' to describe the nature and replication of 'older style' and thus a manner of showing style with purposeful digital defects. Here the sanitary robot on its last legs in Wall-E, one of the last automata still capable of clearing mountains of waste on an abandoned earth is comparatively defective and obsolete as it encounters EVE (Extraterrestrial Vegetation Evaluator), a newer, hovering droid, with speech capability and defense protocols. The lesser machine, Wall-E, with a digitized voice uttering monosyllabic terms reminiscent of the Star Wars (1977) character R2-D2, or more aptly a cuter and smaller version of the Johnny Five robot in Short Circuit (1986), is distinct because of his unique personality: his outmodedness makes him cute and vulnerable, a machine we can root for. In equal measure, Vanellope von Schweetz, in Ralph, is also imperfect: her raspy tone and obnoxious pre-teen attitude mirrors the It's Punky Brewster ani- mated cartoon, a spin-off of the popular live action television sitcom, Punky Brewster that aired from 1984-1988 on the NBC network. The tone is helped along by a real-life though grown-up Punky Brewster-type, Sarah Silverman, an American comedian and actress who provides the celeb- rity voiceover and rambunctious attitude, while the everyman, even Hollywood simpleton of John C Reilly conveys the imperfect character in his live-action roles, for example: Boogie Nights (1997), Magnolia (1999) and, most explicitly, the silly Talladega Nights: Ballad of Ricky Bobby (2006). These characters played by Reilly, in our view, lend to Ralph's animated personality, the hillbilly goon determined to make the best of his unlucky fortunes. Here audiences come to enjoy all three characters' flaws, somehow making each narrative more endearing, and thus more relatable, but also more commodifiable to merchandizing and branding.

Beyond the visual aspects shared by these three characters - a computer glitch (Vanellope), brutish goon (Ralph), and bucket of bolts (Wall-E), they are each determined to fit in with their more perfectly rendered and perfectly performing counterparts. In a relatable context though differ- ent discipline, the 19th-century art critic John Ruskin held the general view of imperfection - one timeworn and we believe - time resistant. 'Imperfection', to Ruskin, is 
essential to great art, because 'imperfection is in some sort essential to all that we know of life. It is the sign of life in a mortal body' (Ruskin, 1853, quoted in Roberts, 2010). Imperfection in new millennium animated films come to celebrate older technology or what 'we know of life' to invoke Ruskin, wherein 3-D computer animation must give itself to more plain but clever styling to stay relevant and based in a familiar though different visuality to our own. In effect, human representation as designed by computer and code is consciously showing error as the human side of computing. Thus, the effort by animators to endow their characters with unmistakable distortions to form, personality and voice should not be understated.

Our other concern is to theorize 'digital labor zones', a new vantage point to analyze digital work viathe Wall-E robot, an automaton that continues his daily task of clearing and hauling debris; an automated labor we equate to 21 st-century creative processes echoed in this film. While in Ralph, the reluctant villain, Ralph, keeps imagining one day he can find the same admiration as his arcade counterpart, Fix-It Felix, Jr., and those who live in the apartment building he continually rampages. As such, Ralph goes about disrupting other video games to reassert his labor power and, in the process, finds new self-worth. In digital terms, he becomes

a rogue operator in the system, [occupying] a symbolic role as the uncontainable element in the digital - in this case, resisting the program. His autonomy and disobedience establish him as the protagonist and generate the film's dramatic conflict, recalling Bukatman's (2012: 146) argument that 'the spark of life that separates an automaton from a living being is precisely its assertion of autonomy. The creation that disobeys does not just come to life: it takes on a life of its own.' (Davis, 2014: 134)

Here both characters are not just pantomimes of humans and human labor activity but also exist in a laboring second reality where work, in discussion of these films, has found less critical attention than it deserves. Our connection then between the imperfect aesthetic and digital labor zones is the codescape. Thus our modest contribution is an examination of Wall-E and Ralph's formation of an animated codescape for both its narrative world as well as a larger commentary on how cinema and gaming have altered perspectival, but more importantly to us, metaphorical expressions of culture as shown through 3-D computer animation.

\section{The animated codescape}

Recently, live-action films have received ample theorization in relation to their inclusion of tropes and motifs of animation and gaming (Brown, 2009; Crawford, 2013; Galloway, 2006; Geiger and Littau, 2013; Gurevitch, 2010; Lowood, 2006, 2009; Ng, 2013; Niedenthal, 2007). This is what Geiger and Littau (2013: 2-3) call the 'trace' of one media's intermedial currency to another. In other words, there is an on-going debate that there is somehow a crossover of all three. In particu- lar, the computational aesthetics of The Matrix (1999) and more recently Life of $P i$ (2011) are obvi- ous examples out of a multitude of digital cinema where a confluence of media is noticeable. In a literal sense, the post-production animation of character mapping and spatial touch-ups continue to transform our optical senses. The bullet-dodging Neo in The Matrix is now one of the most iconic cinematic moments in our 'digital turn' (Galloway, 2006; Rodowick, 2007) as is the Bengal tiger, so life-like in Life of Pi that it is hard to tell, if not impossible to discern, photos of the real animal from those digitally rendered by $\mathrm{F} / \mathrm{X}$ animators. These unforgettable paradigm shifts in digital technology remind us about the integration of computational aesthetics pervading our daily cin- ema-going experience. At the time of the writing of this article, Interstellar (Christopher Nolan, 2014) is perhaps the most astonishing example of advancement in F/X display and modeling because of its threading together of a painterly cosmic galaxy-scape - colors never before seen on the big screen - with a spatially convincing tesseract rolled out in the finale of the film.

As these films illustrate, at least since the early 2000s, we have become accustomed to the slick model surfaces through computational texturing that has built a codified reality leading to forms of hyper-realism; the black hole vortex in Interstellar springs to mind or the literalization of 8-bit realism that structures the virtuality in the Tron reboot in 2010 by Disney. This takes 
form via dif- ferent reflections of light or subsurface scattering that allow for a virtual image, where we see beyond the objects on screen and conclude that there is no longer any materiality to frame our reality. Hence the indexical nature of the image - its origin - ceases to exist. It is the code that is now present in the images we see on screen.

If we follow the definition provided by The Oxford English Dictionary (OED), codified, as a verb and the past tense of 'code', means: '1. to reduce to a code: codify laws; 2 . to arrange or sys- tematize'. Moreover, we can now think of digital images in this way: codified configurations that are mediated by technology. Yet in our era of digital imaging technologies, the codified image takes on a variety of roles - that is, it becomes a new way of seeing; a metaphoric term; and finally, a dominant mode of making film, video games and animation since the 1990s (Hadjioannou, 2012; Murray, 2008; Rodowick, 2007; Simanowski, 2011). To put the codified programming in with digital films' new sense of creating a visuality, we need to think about the digital perfection of space and the inhuman glacis of polygonal surfaces which have led to imperfection in the digital realm. This explication of computer-generated and restructured clunky character design will make up one conceptual angle of this article.

In grand theoretical terms, Arjun Appadurai's (1996) theory about the 'disjuncture' of forces caused by globalization and its ramifications on culture offer us a reflection on the increase in digital technolo- gies to quantify such manifestations. Appadurai puts forth five 'scapes' to conceptualize these effects: 'ethnoscapes', 'technoscapes', 'financescape', 'mediascapes', and 'ideoscapes'. We can understand the five dimensions as placeholders that articulate a polycentric culture taken under globalism. As such, we would like to fissure the 'mediascape' into another form, what we signal is a minor change to this scape, that of the codescape. Here the image is vital to support Appadurai's thesis that

\footnotetext{
The image, the imagined, the imaginary - these are all terms that direct us to something critical and new in global cultural processes: the imagination as a social practice. No longer mere fantasy (opium for the masses whose real work is elsewhere), no longer simple escape (from a world defined principally by more concrete purposes and structures), no longer elite pastime (thus not relevant to the lives of ordinary people) and no longer mere contemplation (irrelevant for new forms of desire and subjectivity), the imagination has become an organized field of social practices, a form of work (in the sense of both labor and culturally organized practice), and a form of negotiation between sites of agency (individuals) and globally defined fields of possibility. (p. 31)
}

The image, like the scape, is a metaphor; it also provides clues to 'social practices' particularly digital labor that has made the codescape so central to work processes, which we shall return to later in this article. For now, the codescape is a cultural process, whereby its spatial and techno- aesthetic potentiality is relevant to conceptualization of our digital environment and its imperfect images. The imperfect aesthetic infers, in our view, the increasing demand or preference for impre- cise characters and their digitally animated worlds. In other words, imperfect rendering through astutely designed digital animation is fixated less on the presentational responses often so desired when the latest effects packages are tied to digital animation and more about designs and character traits that audiences can relate to. To clarify what we mean by presentational, we borrow this criti- cal term from Michele Pierson (2002) one she usurps and then alters from Charles Musser's view of early cinema and presentationalism - whereby to facilitate, according to Pierson, a deeper dis- cussion of special effects in both analog and digital orientation, images must be thought of against or in relation to the representational. Animation, much like cinema of any time period, can be viewed by its 'novel capabilities' to flaunt the latest technologies 'rather than their ability either to suggest a story or to represent the world at large' (pp. 118-119). Whether novel or not, 3-D com- puter animation under analysis in this article makes use of visual effects as a presentational aspiration but these films also attempt to deepen the narrative and cultural impact of the material through representational means. Conceiving the linkage between presentational aesthetics and representa- tional aspirations, Wall-E and Wreck-It Ralph come to reflect more mature or overtly adult themes found embedded in the characters and worlds they revolt against: they seem 
disenfranchised by or critical of environmental degradation, waste, divisions of labor and unbridled consumption in Wall-E to digital labor exhaustion, manufactured obsolescence and control society in the vein of Foucault and techno-nostalgia in Ralph.

Furthermore, the codescape is a world enclosed by something, whether a window, wooden frame, screen, monitor, display, interface or processor, it is a view of a given reality, one that comes to represent things much larger than what the literal aperture or opening allows us to see or articu- late at first glance. It can, on the one hand, frame perceptual aspects of the world in front of our eyes; yet, on the other hand, it provides the conceptual means to go beyond what is seen, the struc- turing of algorithms beneath. The latter offers often fraught, fragmented implications for culture that complement the imprecision of characters found in Wall-E and Ralph. It is anything but a Koonian postmodernism of the 1990s, whereby 'cast metal sculptures, virtual objects are hollow - code, like air, fills their voids, and their surfaces are a reflective chrome. They are mirror images of undifferentiated, mass-produced consumer goods' (Stallabrass, 1996: 90). The codescape articu- lated in Wall-E and Ralph is therefore grasping not only the aesthetic changes to video games and cinema as animated comparativism, but also how such computational worlds - specifically the digital's hyper-realism or its smoothness triggers a return to less perfected aestheticized images; or the imperfect aesthetic as reflexive concept in 3-D computer animation.

Let us briefly turn to one scene in Ralph that exemplifies this notion of the codescape and the imperfect aesthetic. About halfway through the film when Candy King enters the game matrix a zone of web-like code suspended in the unrendered blackness of computational, codified space, his intention here is malicious - he seeks to neutralize Vanellope's glitch in the program because

he is afraid of her altering the game world of Sugar Rush, the female-centered racing game in Ralph. Once King Candy securely attaches himself to the castle room by candy-floss rope - a fully rendered animated space outside the blackness of the computer milieu he is entering - he floats over to the matrix and pulls Vanellope's character icon out of operation, acknowledging her imperfect presence (and later his own) in the film. Outside the diegesis, we might claim, Moore's intention is to visualize what is behind all cinema, animation and video games in our digital era, what we would call an algorithmic non-space, devoid of perspectival imagery; it is a skeletal architecture in all three media that is now more relevant to talk about, visualize, and theorize. It is a construct of order that seldom requires or administers imprecise commands or codes. Yet it is precisely how we link the digitally animated character design and cultural preference for such design to human error outside the machine world from which it was programmed or rendered that makes it a new style in 3-D animation.

Perhaps another example is required. The glitch character named Vanellope comes to signify the error in coding, a breach between code and rendered aesthetic, an outcome of games being run on computers with insufficient RAM; or in cinema and 3-D computer animation when illegal downloads of films are acquired and reveal the skeletal features of the pre-rendered and pre- modeled processes made visible to audiences. In fact, many prefer this imprecision because it shows what is more often concealed normally (something that is common in countries such as Nigeria and India where piracy is rampant). Nonetheless in Ralph, Vanellope embraces her socalled 'player' flaw according to other characters and builds a race track and dwelling in another, unknown 'hidden' zone in Sugar Rush. Determined to enter the race, she sustains her character's life outside the game world by trying to fulfill her dream of one day competing in the daily go-cart races; she manages this only after encountering Ralph, another glitch and the Other character in the Sugar Rush diegesis. It is only then that Vanellope is able to use her imperfection and 'girl power' to her advantage.

\section{Imperfection 2.0: History, new style and cultural references}

Deliberate imperfection in animation has a distinct origin in high modernist practices in visual art, film, animation, poetry and literature (1900-1930). More precisely, imperfection emerged 
out of the avant-garde tradition before the Great War and during the interwar years in Europe. Though live action film from this period has peaked curiosity and much critical survey of its production and reception, it was animation - experimental and daring in its formal presence that influenced many filmmakers across the continent. Russian avant-garde film before the October Revolution and with some limited work afterwards adhered to a new direction for the animation medium in the interwar years: a geometry of abstraction. But it was the Italian Futurists, those people of techno- logical worship who caught the attention of Vertov and Eisenstein. Due solely to the Futurists' mechanization and abstraction of images, Soviet filmmakers apprehended not their own aesthetic symmetry but rather a new form of aesthetic unpredictability inspired in the work of Giacomo Balla. One is reminded of Balla's two seminal oil paintings as a Futurist: Dynamism of a Dog on a Leash (1912) and Speeding Automobile (1913). In Dynamism, the influence is not only to mechani- cal synergy, his observant depictions of things in motion need no further comment, yet we might also point to Balla's encounter, presumably with graphic art and animation in Italy before the Great War. Emile Cohl's Fantasmagorie from 1908 was well-known in Europe and was an animated film surely influential to Balla. Concomitantly, the circulation of avant-garde animation amongst practitioners in Europe is becoming better documented (Beckman, 2014; Leslie, 2002; Taylor and Christie, 1988) and the animation of life is another way to interpret the dog as kinetic element in the ever-evolving modern city. Like the geometry of form for his dog in motion, Balla's Speeding Automobile, violent-looking, with its prism-like, protruding fractals could be thought of as mim- icking the movement in Fantasmagorie or the fragmented intertitle cards in cinema, both possible influences on the Futurist painter. Cinema, much like animation at this time, was comprehended as mechanical imprecision and, as such, becomes implicated in a 'lyrical effect' of 'artistic aestheti- cism' (Leslie, 2002: 16-23).

Such a merger between Bolshevik filmmakers and Futurist aesthetics (though drained of the conservative ideology) is shared by Martin F Norden (1984: 110), who explains:

The latter innovation fascinated him [Vertov], and during the early 1920s he mixed Futurist and Bolshevik principles and applied them to film. The result was his 'Kino-Glaz' (Cinema-Eye) theory, which he put into practice with the production of a film entitled, appropriately enough, 'Kino-Glaz' (1924). As cinema historian Albert Leong noted, the film incorporated two principles which were to remain at the center of Vertov's cinema: the power of technology, hence the superiority of the mechanical camera-eye to the human eye.

There is no doubt today that the mechanical camera-eye now aided by computer software to pixe- late reality has in some ways fulfilled the Futurist's (and Vertov's) vision for technoaestheticism derived principally by machines. But equally, the techno-aestheticism organized by machines is the meshwork of artifice, one in need of differentiation then, and now. Ideology was also differentiated by Italian Futurist painters and Soviet filmmakers and animators. What this meant in the interwar years was differences in ideological functions for the medium; a process where animation became political: one for the purification of obsolete society through mechanized annihilation (Futurism and later Fascism) and the other to educate and propagate egalitarian ideas (Socialism).

What is different in the 21 st century, though throughout history there has always been a desire to challenge more classical styles perceived by public tastes, is a search for a style of interest in ways common with older technology. 3-D computer animation today is not advocating the return of older technologies but to reboot, repurpose or restore those aging aesthetics or decadesold recognizable styles in software that can extend the shelf-life and thus establish the popularity of retrograde commodities. To recall Eisenstein's famous words about 'plasmaticness' in animated work, its flowing diversity of forms is a way to think about 3-D computer animation's backwards glance toward the visuality of older cinema and video game culture (Eisenstein, quoted by Leslie, 2014: 31); it is a rearview mirror effect in the seemingly endless production of postmod- ern cultural objects.

To us, however, imperfection is not a counter-intuitive action by artists consciously liberating 
their spirits against the giant conservative forces found at Pixar and Disney, but as a new commer- cial goal in 3-D computer animation. The work at these places is so refined and controlled, such that 'technically deflationary' practices are attractive because they hark back to older media (Roberts, 2010: 79). This imperfection is shared with cultural nostalgia for everything from the early years of computer gaming such as Worm War I from the 1980s (Gurevitch, 2010) to older, celluloid cinema of say DW Griffith in the 1910s. Yet it is here where we have all become more sentimental about technology of the past, whether half a century ago (the tinsel glamor of Hollywood cinema) to just over one decade ago in video games (the digital James Bond in the first-person shooter template Golden Eye). We see the digitized notion of nostalgia in Deborah Tudor's (2010) articulation of a 'technostalgia', another way to understand our contemporary cultural sphere.

Yet such techno-fetishism is not without worry. In fact, we share in Mihaela Mihailova's (2014) analysis of animated science-fiction features that 'articulate anxieties about the high degree of artistic mastery facilitated by advanced technology' which she equates as embedded in film and animation itself (p. 131). What Mihailova aptly calls computer animation's ability to foreground 'its technological and artistic control over the image as feat to marvel at' does overlap, we believe, our notion of the imperfect aesthetic precisely because of the controlled style for character design found in many animated feature films. In other words, the imperfect aesthetic we are positing is not a design that is not resistant to the commercial style found in Pixar and Disney's recognizable aesthetic.

Historically, Disney constructed strong rules and a formulaic, Taylorist mode of manufacturing animation, especially for cel designs. They strove and still strive to make animated films in an iconic style perfected in their own particular aesthetic - characters that are conflations of cartoon and human physiognomy - always rendered through smooth, seamless editing; designs that were sig- nificantly advanced via complex modeling and rendering software - such as Maya, 3DS Max, Animation Master and now Hyperion - since the medium was digitized. This is guided by what Mihailova observes is 'the artists who drive software development and shape software according to their needs and creative vision' (Tarantini, 2012: 267, quoted in Mihailova, 2014: 145). Thus perfec- tion of characters and its delivery system was the house style and mode of production at Disney and now Pixar. And although many animators have tried to escape from Disney and Pixar's design work, choked by such perfectionism, it is ironic that imperfection, purposeful imperfection in character design is now 'in'. Nowadays, many young animators tend to express imperfection as 'error', one we now watch out for but also embrace in the purposeful automata of characters. Toy Story (John Lasseter, 1995) comes to mind, with its metaphor of the analog embedded in the toy technology in the narrative: Woody is envious of and annoyed by Buzz Lightyear, equipped with his digital voice and light-up laser wrist blaster. Ironically, at the end of the film, Woody is given a privileged posi- tion in the narrative, as nostalgia and imperfection win out over the digital cosmonaut.

Like Toy Story, Wall-E and Ralph employ such imperfect character design in the diegetic world rather than within the design process itself. And this is a crucial point in our article. Imperfect character design is a deliberate move, more about nostalgia and 'de-skilling' to borrow from art historian John Roberts. For Roberts (2010) de-skilling is an 'aesthetic propriety, undoubtedly ugly, technically deflationary and fragmented' (p. 94) that can be seen in the work of modernist painters associated with the Dadaists and Futurists. Such work is also less about clean-looking, flawless aesthetic, or to purport a form of realism, and is instead more about what such imperfec- tion implies or allegorizes.

If we think about characters found in much 3-D computer animation, it seems to be about the displacement of smooth, flawless design. For instance, Ralph is proportionally awkward in order to draw attention to his disadvantaged status and identity as cartoon brute - a red-haired version of the mean-spirited Bluto character in Popeye - the same goes for Vanellope, gap-toothed, boyish and hyperactive compared to the other, prettier female racers. To return to Ruskin, he pointed out more than a century and a half ago, 'the difference between the organic (or great) and the mechani- cal (common) is very little in terms of appreciation' (Ruskin, 1853, quoted in 
Roberts, 2010). In other words, the sublime for Ruskin is found in the painterly works of William Holman as much as in the mechanical reproduced etchings in William Hogarth's pictorial satire of upper-class life in London; both show us the aura of originality in painting and the reproducibility of newspaper prints, the latter illustrating imperfect worlds as allegories to real-life social mores: class stratifica- tion, elitism, greed, over-consumption and unhygienic spaces. Animation today could be equally celebrated in terms of its equivalent motivation to develop clumsy, disproportionate as well as disadvantaged characters that also purvey attitudes and social criticisms. The characters - Wall-E, Ralph and Vanellope whom we are analyzing are the underdogs in their respected narrative worlds. This, in turn, points less to a presentational emphasis, one emphasized in Disney animation of the 1940s onwards, something that now matters less in this context as 3-D computer animation, as their cultural worlds refract our real world problems.

To return to imperfection in aesthetic terms, Julian Stallabrass (1996) suggests in his analysis of computational aesthetics:

Again, increasing naturalism - and not just fractals but greater resolution and more colors than the human eye can distinguish - means games are gradually losing their specific look in favor of a 'style' which is to some degree beyond the control even of the programmers. (p. 88)

We could label, to some degree, Wall-E and Wreck-It Ralph as closer to mathematical visuals, where the digital details poke through, and how the narrative emphasizes the details of an imperfect world, full of 'deliberate inchoateness' (Roberts, 2010: 79). Yet these mathematical visuals need to be cut from the cold logic of programming and given over to the human aspect of marred, fallible characters, which are qualities that children and adults alike adore, from Snow White and her seven dwarfs to Fat Albert and his lovable but imperfect Harlem buddies to current slouchy 3-D computer-animated characters such as Po (voiced by Jack Black) in Kung Fu Panda. These ani- mated films - some cel drawn and others rendered on computer software - constitute to us the purposeful imperfection being used in 3-D computer animation.

Aesthetically, Chris Carter (2014: np) sees imperfection as we do in Wreck-It Ralph, writing:

... [Wreck-It Ralph] adhere[s] to a different set of guiding design principles referred to as a 'shape language.' The term 'shape language' refers to a design philosophy that 'unifies the film by using the same visual vernacular and guiding design principles throughout every scene and setting'. Fix-It Felix, Jr. for example, uses a square shape language to reflect the 'squareness' of the 8-bit pixel art of early video games whereas the triangulation of the polygonal environments of first-person shooters informs Hero's Duty.

These decade-specific design principles or 'shape language' in Carter's formulation are thus nos- talgic throwbacks to arcade games and video game systems such as Atari of the 1980s but also the 1990s with game systems such as Sega. All systems of imperfection in retrospect have come to set new standards for modeling and its character designs. In Wall-E, the imperfection is manifest in the robot itself. Completely obsolete on the discovery of EVE, a new composite hovering drone, white and black with an Apple-like appearance similar to i-pads and i-Macs. Yet despite Wall-E's worn- look, we are fond of the ever-cheery robot, whose rusty, piecemeal appendages, and dusty exterior make him all the more endearing.

In the case of Ralph in Wreck-It Ralph, his appearance is based on video games of the 1980s: for example, the Golden Age of arcade 8-bit games; here we are reminded of Donkey Kong and Frogger from this period. As Carter (2014: np) discusses, the 8-bit reality is vital to understand the

computer architecture upon which early game consoles were built. For example, in the early 1980s, the popular Nintendo Entertainment System (NES) and Sega Master System both featured an 8-bit microprocessor. Compared to modern computer architecture that incorporates 64-bit systems, the 8-bit model was slow and restricted the amount of memory available for processing data.

Size and off-screen relationships are worth flagging up here, too. Davis, another scholar on 
digi- tal animation follows a similar line of thought to Carter's and our own, finding:

Characters with differently sized bodies inhabit extensive off-screen virtual spaces that suggest a spatial vastness out of players' reach, and are paired together as correctives to the destabilizing lack of a scalar constant; there seems to be no 'normal' size against which characters are scaled, small or large, and so they are situated in opposition to one another and the environment they inhabit. Through differences in scale, as well as juxtaposition of miniaturized avatars with the vastness of networked videogame space and the external world of the arcade, Ralph explores themes of instability and the loss of self in a digital world, within a digitally animated film. (Davis, 2014: 127)

As Carter emphasizes the 8-bit aesthetic and Davis stresses scale, they get at what we are arguing is the imperfect aesthetic of these digital worlds created by computer. It is at once cultural as much as it is aesthetic in Ralph and Wall-E, worlds that come to reflect the profound and ubiquitous changes to our societies.

\section{A bubblegum visuality and 8-bit work space in Wreck-It Ralph}

Games studies now form one important component in the cultural sphere of the 21st century. The field continues to gain intellectual capital in the academy, with places such as MIT in the United States, UMEA in Sweden and KIAST in South Korea each turning to analyses of the aesthetic, industrial, and human-computer interactions. Studies emerging from these institutions have dili- gently illuminated digital and analog feature elements in our techno-visual economy. In smaller research output, however, work is being developed on the cultural aspects of games and interface, and even less still on animation's representation of gaming in its own narration (Galloway, 2006). Signs about the quarry of information abounds; for instance, Sherry Turkle (2005), who writes:

\footnotetext{
We have become accustomed to opaque technology; we have learned to take things at interface value. If the transparent early IBM PC modeled a modernist aesthetic technological aesthetic, the Macintosh-style interface was consistent with a postmodern one whose theorists have suggested the search for depth and mechanism is futile, and that it is more realistic to explore the world of shifting surfaces than to embark on a search for origins and structures. (pp. 267-268)
}

Our research thus far pertains to how animation patterns its own visual imperfection, which stretches from Futurist art of the 1910s to Soviet avant-garde films of the 1920s and 30s to the first decade in the 21 st century via $3-\mathrm{D}$ computer animation. Like animation, video games are also predicated on the reimagining of lifelikeness and reality that ultimately fail in such a process of rendering them with the computer technology of the time. But this represents an aesthetic idealism that is ultimately untenable. Media such as video games and animation need to be thought of in terms of the periods in which they emerged and the cultural environments they construct and record. Commenting on the connection of video games and their embeddedness to the larger visual economy, Alexander Galloway (2006) writes:

A video game is a cultural object, bound by history and materiality, consisting of an electronic computational device and a game stimulated in software. The electronic computational device - the machine, for short - may come in a variety of forms. It may be a personal computer, an arcade machine, a home console, a portable device, or any number of other electronic machines. (p. 1)

Thus, we can associate the video game with animation - its cultural overlap - whereby the characters in Ralph occupy two worlds: that of avatar for its users in 2-D form and of AI, 3-D lives once the user leaves the arcade. Simply put: these animated worlds are miniaturized versions of our actuality, though they are much more naive. In the diegetic animated world of Ralph we find an afterlife of video game characters that inhabit a virtual world - who mingle in-between differ- ent game genres in a terminal of sorts - the Grand Central of 8-bit gaming - and are 
electronically transported back to their native game zones each day when the arcade opens. Only later do we learn of Ralph's failed counseling with the other villains, where he then seeks refuge in another offline game, Hero's Duty. It is here that he impulsively decides, after meeting another warrior character from a Saloon video game space, to try and win a medal in the combat game zone Hero's Duty; in the process, Ralph seeks to gain the respect of the characters in his videogame world of Fix-It Felix, Jr.

These characters are thus anything but 'static computer code' in Galloway's words (2006: 2) but are instead endowed with a certain degree of intelligence. Here such intelligence, however, is a cognitive ability, one that binds them to their codified worlds. Limited to and generally controlled by the code of the program, they still show genuine, though make-believe feelings. In sum, 'Wreck-It Ralph explores affective associations with videogame worlds in a manner similar to the way Toy Story explores the world of childhood through toys' (Davis, 2014: 133). When 'the phan- tasmagoria is breached, and the structure of the game peeps through' they still inhabit the charac- teristics of the DNA of the computer code, and the digital world that binds them to it.

Moreover, the characters in Wreck-It Ralph perform their coded realities as guided by users and machine; however, interestingly, they also exist in a 'second reality' in Caillois and Barash's (1961) notion, one beyond the gaming function. Here they desire things through simple life-making activi- ties in their off time. When not laboring in their game worlds they display emotions and desires: for example, love, envy, ambition, validation, honor, disobedience - each driving them to be more complete 'characters'.

\section{Immaterial labor in the game and the creators of animated 3-D work}

Gaming and 3-D computer animation represent a new aspect in our immaterial labor society, whereby service work can drain away ambition. In Wall-E, the metallic robot does machine labor but it is at night that his immaterial labor kicks in, presumably, through logistical command: he views classic Hollywood films, 'viddied' from old files in order to feel nostalgia and attachment. The robot's distraction and repetitive work are made pleasurable through the constant re-viewing of the Hollywood pleaser, Hello, Dolly! (Gene Kelly, 1969). Presented in one of the more touching early scenes in Wall-E, is the robot's cognitive reflection that comes from a newly developed AI intelligence; one that allows him to feel, or, more likely tells him to feel, nostalgia. Perhaps a more apt narrative reflection on immaterial labor is found in the banal routines of work central to Ralph. Here we find Ralph displaying a despondent candor in connection to his destructive behavior, especially when he is activated to play the part of video game villain. This points to what Stallabrass (1996) calls 'signs of labor that are apparent in computer gaming, where physical strain of heavy, repetitive tasks is replaced by the digital twitching demanded by the control system' (p. 100). Thus Ralph spends his downtime 'offline', 'twitching' with frustration when the arcade is closed, brood- ing on a pile of bricks next to his ramshackle dwelling, pieced together from discarded digital bricks, white window frames and detritus. Ralph's ambition to challenge his menacing game char- acteristic is dashed, as he repeats, day in and day out, the same digital labor of destruction. The landfill in terms of refuse in Ralph's codescape in Fix-It Felix, Jr. serves as a metaphor for dis- carded technology, as Ralph reflects about the nostalgia for older arcade video games which leads audiences to ponder our constant need for newer computational devices and gaming.

We propose going beyond outmoded technology to finish this article by asking to what extent immaterial labor appears in Ralph. We view the subtle subtext of drudgery in immaterial performa- tive labor as it is buried in Moore's 3-D animated film as brilliant commentary on creative industry jobs. We can view such work in this film and others as analogs to the US animation industry and its immaterial labor force. The notion of repetitive work in Ralph is also a commentary on creative work and the futility of maintaining a form of labor exertion, one that these days will seldom lead to either fulfillment or job security. Thus, we believe a new mode of work, with the steady growth of the video game industry allowed this type of digital labor, 
which is also inherent to contempo- rary animation design, one critiqued or rather allegorized in Ralph. Locating this turn toward immaterial labor, we can see historically this taking form when industries such as coal, automobile production and agriculture were soon outmatched by the lure of the finance and service sector industries in the 1970s onward. Later, creative industries, particularly video games which corre- spond to an increase in an immaterial workforce were created to manage new services and new products (Florida, 2002). This immaterial workforce, initiated in the 1970s, began to splinter work- ing-class production into newer, more cognitive or service production realms that made possible non-tangible commodities: from stock portfolios managed in Geneva, to timeshares held in Bermuda to concept branding in London. But the shift to non-tangible commodities illustrates another transformation. According to the Italian autonomous Marxist tradition, one chiefly articu- lated by Maurizio Lazzarato (1996), 'the factory without walls' is also a place where the labor that produces the informational and cultural content of the commodity was radically reorganized and rethought. Cultural work is tied not only to the animated diegetic making in Wall-E and Ralph - the toil of creating computergenerated imagery - but also the diegetic processes by which both robot and human figures participate in: cybernetic realities and repetitive toil that is a service for its user (consumer as player). Lazzarato was concerned with this labor, implausible not to think about today, as he stresses the fact that

... where the skills involved in direct labour are increasingly skills involving cybernetics and computer control (and horizontal and vertical communication). On the other hand, as regards the activity that produces the 'cultural content' of the commodity, immaterial labor involves a series of activities that are not normally recognized as 'work' - in other words, the kinds of activities involved in defining and fixing cultural and artistic standards, fashions, tastes, consumer norms, and, more strategically, public opinion. (p. 46)

If Lazzarato points to the 'living labor within production' it is also important to reflect on how others counter this position. For Marx, all labor in capitalism is simultaneously material and immaterial. It is material in the sense that it involves a physical labor process (irrespective of whether the product is a material good or a service) and immaterial in the sense that competition reduces these different processes to quantities of what Marx calls abstract social labor. We recog- nize Marx's conception of 'abstract social labor' yet still believe that certain immaterial positions in late capitalism, for example the role of the 21 st-century security guard, and what they produce in their protective services for a particular industry is important. It is these security guards' use of digital technology via CCTV cameras and motion detectors that constitute a type of immaterial labor that can be performed from a remote office, not on the premises, taking the place of patrol and surveillance done on foot. Therefore, we will not dispense with Marx's ideas about social labor nor shall we dispense with Lazzarato's autonomist understanding because they are both beneficial to conceptualizing the changing forces imposed upon the artist/animator/designer in our post-Fordist world.

At the same time that immaterial labor began to grow worldwide there were also new strategies under neoliberalism to structurally weaken global workers' movements. Since the probusiness environment was looking to emphasize and increase managerial power to regulate and discipline working-class insurgency, this marks one of the defining features of neoliberalism then and now. In other words,

As the delegation of management to a salaried personnel advanced, a sharp polarization occurred between the upper and lower strata ... the division of tasks was not merely functional but hierarchical, and this hierarchy still defines a basic feature of social relations in contemporary capitalism. (Duménil and Lévy, 2011: 94)

Digital animation professionals are increasingly lumped into contract-based, insecure workforces, noted for their creative labor; as such, animators are attached to the larger professional pools of creative labor, including part-time university lecturers, visual artists, 
gallerists, curators, designers, among others active in the creative industry. Not only are Pixar and Disney guilty of promoting this type of insecure work - one only has to gesture to the credits found at the conclusion of recent 3-D computer-animated feature films and be astonished to learn of the hundreds of animators and digi- tal effects artists, and wonder how many are being paid a living wage? Let alone contemplate how many others are even on contract work and are subcontracted in firms that Disney employs.

Roberts (2010: 68) put this process in artistic versus production terms, writing that:

This shift from the artisanal to the executive, nominative, and immaterial in art is the point where the postRenaissance definition of artistic creativity as the autonomous and expressive rendition of craft-skill is finally destroyed; the deflation of painterly technique in modernist painting from 1850 to 1915 is, in this sense, an internal prefiguration of this crisis. In this respect, it is possible to trace the emergence of the modern artist under capitalism as comparable to the loss of the artisan and 'integral' creativity of labour within the labour process. The rise of the post-artisanal labourer, through workshop, automated factory and office, parallels the decline of artisanal skill in artistic production; and this, of course, is what both Marx and William Morris generalize as being the overwhelming destiny of human capacities under capitalism: namely capitalism's general diminishment of all-round human creative powers in the interest of narrowlydefined categories of productive labor and free creativity; and, concomitantly, this is why Morris was so interested in the pre-Renaissance medieval workshop as a model of socialized creativity, given the ways in which it brought the possibility of freely-directed creative work into alignment with production.

Here Roberts draws our attention to William Morris's Victorian workshops that during this period made interior design a livable profession for its designers and one that working-class British could afford. Yet to contemporize these Disney-like workshops - animation studios they are still hives of creative activity to be sure, but places where energy and toil do not necessitate a job-for-life position. Frustration might be seen as a metaphor to Ralph's destructive actions. Here we under- stand the repetition of his action - smashing the apartment building façade, window frames, glass and trim as leading to malaise after years because he must act like (but is not outside the game's labor) a rampaging goon in Ralph. Instead of being accepted by the apartment residents in Fix-It Felix, Jr., Ralph is judged poorly and not allowed to join the social community once the game is idle and their 'work' is complete (destroying, fixing or acting). His video game depression leads to bad guy/creature therapy sessions, a place where they can discuss their problems and the stereo- types they face as typecast villains in the wider codescape. Work is done but never discussed by the characters, it is articulated as performance, never a job; a role being played but never intended to be thought of as intense laboring, even in the game world and it is here that our critique of immate- rial labor complements the narrative scope of this valuable 3-D computer-animated film. We must remember that Ralph runs from the toil he does in his digital world rather than confront, head on, the fact that the skills he and those characters in Fix-It Felix, Jr. flog are no longer valuable in the diegetic world. Indeed, outside the codescape, in the arcade, Fix-It Felix, Jr.'s monetary value as game has also waned and it is only a matter of time before it too will be obsolete.

\section{Conclusion}

As we have strenuously implied in this article - the codescape - that computer generated field of cultural diversity in animation and other media is also a place where older notions of aesthetics and questions of labor can be renewed and reinvigorated when thought of in the context of our digital turn. As our second term, the imperfect aesthetic, made apparent, we believe, a purposely degraded aesthetic that has and continues to be implemented by animators and is sought after by audiences in the millennial period. Vulnerability is connected to not just what the design shows us - pur- posely facile character design in animated form and personality - but also a narrative strategy whereby audiences find themselves drawn to flaws and weaknesses they might otherwise see in themselves. For example: a lack of confidence (Ralph); underappreciated and overworked (Wall-E, Ralph and Vanellope); outmoded skills and personalities (Wall-E and 
Ralph); outspoken and impetuousness (Ralph and Vanellope); shunned and considered the outsider or Other in their respected worlds (Wall-E, Ralph and Vanellope). Put another way, imperfect visions of the world keep society at pace with the proliferations and implementations of computer-aided technology and culture at speeds now almost incomprehensible.

To continue to ponder this question of imperfection that we validated through a variety of historical and theoretical approaches - especially Roberts's (2010) notion of de-skilling and technically deflationary images in art history - we also arrived at how such imperfection was created. Thus our notion of immaterial labor zones was stressed in relation to Ralph and, to a lesser extent, in Wall-E. Although an adventurous proposition on our part, the fact of the matter is that, given the immense amount of work being done to create these sophisticated computational animated worlds - the endless immaterial laborers found not only in the US and the UK but also in South Korea and Japan, among other nations known for producing impressive and culturally sought after 2-D and 3-D animation, is sorely under-appraised, other than the scholarship of Joon Yang Kim (2014). Not willing to stop the conversation about these developments in Disney 3-D computer animation, we hope to keep developing these ideas as the field of animation becomes, much like film studies, more interdisciplinary and thus more supportive to aesthetic and sociological formations, continu- ally being redrawn and appropriated in media that is both digitally created and reflexive and inclu- sive of other media.

\section{Funding}

This research received no specific grant from any funding agency in the public, commercial, or not-forprofit sectors.

\section{Note}

1. What we are referring to here are the following 3-D digitally animated films from roughly 2000 onward that were being produced globally: Cars (USA, 2006), Bee Movie (USA, 2007), Beowulf (USA, 2007), Big Hero 6 (USA, 2014), Chicken Little (USA, 2005), Cloudy with a Chance of Meatballs (USA, 2009), Despicable Me (USA, 2010), Dinosaur (USA, 2000), Dragon Blade (China, 2005), The Emperor's Secret (Finland, 2006), Especial (Russia, 2006), Flushed Away (UK/USA, 2006), Freddy Frogface (2011, Denmark), Friends: Mononoke Shima no Naki (Japan, 2011), Gnomes and Trolls: The Secret Chamber (Sweden, 2008), Happily N'Ever After (USA/Germany, 2007), The Happy Cricket and the Giant Bugs (Brazil, 2009), Happy Feet (Australia, 2006), Ice Age (USA, 2002), Jungle Master (China, 2013), Khumba (South Africa, 2013), Kung Fu Panda (USA, 2008), Legends of Oz: Dorothy's Return (India/ USA, 2014), Legends of Valhalla: Thor (Iceland, 2011), Luke and Lucy: The Texas Rangers (Belgium/ Luxembourg/Netherlands, 2009), Monsters, Inc. (USA, 2001), Mug Travel (South Korea, 2007), Pirates in Callao (Peru, 2005), Plumiferos (Argentina, 2010), Postman Pat: The Movie (UK, 2014),

Rio (USA, 2011), Shrek (USA, 2001), The Snow Queen (Russia, 2012), Toy Story (USA, 1995), UP (USA, 2009), Yona Yona Penguin (France/Japan, 2009).

\section{References}

Appadurai A (1996) Modernity at Large: Cultural Dimensions of Globalization. Minneapolis: Minnesota

University Press.

Beckman K (ed.) (2014) Animating Film Theory. Durham, NC: Duke University Press.

Bissonnette S (2014) Introduction to the special issue: Animating space and scalar travels. animation: an interdisciplinary journal 9(2): 117-123.

Brown W (2009) Beowulf: The digital monster movie. animation: an interdisciplinary journal 4(2): $153-168$.

Caillois R and Barash M (1961) Man, Play, and Games. Urbana: University of Illinois Press.

Carter C (2014) Adapting '8-bit' motion style to 3D computer animation for Wreck-It Ralph. Mediascape: 
UCLA's Journal of Media and Cinema Studies, Fall.

Crawford A (2013) The digital turn: Animation in the age of information technologies. In: Stable CA and Harrison M (eds) Prime Time Animation: Television Animation and American Culture. London:

$$
\text { Routledge, 110-130. }
$$

Davis A (2014) Never quite the right size: Scaling the digital in CG cinema. animation: an interdisciplinary journal 9(2): 124-137.

Duménil G and Lévy D (2011) The Crisis of Neoliberalism. Cambridge, MA: Harvard University Press. Florida R (2002) The Rise of the Creative Class: And How It's Transforming Work, Leisure, Community and Everyday Life. New York: Perseus Book Group.

Galloway A (2006) Gaming: Essays on Algorithmic Culture. Minneapolis: Minnesota University Press. Geiger J and Littau K (eds) (2013) Cinematicity in Media History. Edinburgh: Edinburgh University Press.

Gurevitch L (2010) The cinemas of interactions: Cinematics and the 'game effect' in the age of digital attractions. Sense of Cinema 57: 4-9.

Hadjioannou M (2012) From Light to Byte: Toward an Ethics of Digital Cinema. Minneapolis: University of Minnesota Press.

Halpern O (2015) Beautiful Data: A History of Vision and Reason since 1945. Durham, NC: Duke University Press.

Jameson F (1991) Postmodernism, or, the Cultural Logic of Late Capitalism. London: Verso.

Kim JY (2014) South Korea and the sub-empire of anime: Kinesthetics of subcontracted animation production. In: Bolton C (ed.) Mechademia 9. Minneapolis: Minnesota University Press.

Lazzarato M (2006) Immaterial labor In: Virno P and Hardt M (eds) Radical Thought in Italy: A Potential

Politics. Minneapolis: Minnesota University Press.

Leslie E (2002) Hollywood Flatlands: Animation, Critical Theory and the Avant-Garde. London: Verso. Leslie E (2014) Animation and history. In: Beckman K (ed.) Animating Film Theory. Durham, NC: Duke

University Press, 25-36.

Lowood H (2006) High-performance play: The making of machinima. Journal of Media Practice 7(1): 25-42.

Lowood H (2009) Warcraft adventures: Texts, replay and machinima in a game-based story world. In: Harrigan P and Wardrip-Fruin N (eds) Third Person: Authoring and Exploring Vast Narratives. Cambridge, MA: MIT Press, 407-427.

Mihailova M (2013) The mastery and machine: Digital animation and fantasies of control. animation: an

interdisciplinary journal 8(2): 131-148.

Murray T (2008) Digital Baroque: New Media Art and Cinematic Folds. Minneapolis: University of Minnesota Press.

Ng J (2013) Understanding Machinima: Essays on Filmmaking in Virtual Worlds. London: Bloomsbury Academic.

Niedenthal S (2007) Shadow play: Simulated illumination in Game Worlds' Worlds in Play. International

Perspectives on Digital Game Research 21.

Norden MF (1984) The avant-garde cinema of the 1920s: Connections to Futurism, Precisionism, and

Suprematism. Leonardo 17(2).

Pierson M (2002) Special Effects: Still in Search of Wonder. New York: Columbia University Press. Roberts J (2010) Art after deskilling. Historical Materialism: Research in Critical Marxist Theory $18(2)$ :

77-96. 
Rodowick DN (2007) The Virtual Life of Film. Cambridge, MA: Harvard University Press.

Simanowski R (2011) Digital Art and Meaning: Reading Kinetic Poetry, Text Machines, Mapping Art, and Interactive Installations. Minneapolis: University of Minnesota Press.

Sito T (2013) Moving Innovation: A History of Computer Animation. Cambridge, MA: MIT Press.

Stallabrass J (1996) Gargantua: Manufactured Mass Culture. London: Verso, 80-110.

Taylor R and Christie I (1988) The Film Factory: Russian and Soviet Cinema in Documents 1896-1939. Cambridge, MA: Harvard University Press.

Tudor D (2010) Light bouncing: Digital processes illuminate the cultural past. Jump Cut: A Review of Contemporary Media 52, Summer.

Turkle S (2005) Computer games as evocative objects: From projective screens to relational artifacts In: Raessen J and Goldstein J (ed.) Handbook of Computer Game Studies. Cambridge, MA; MIT Press.

\section{Author biographies}

Keith B Wagner is an Assistant Professor of Film and Media Studies and Global Studies at Hongik University in Seoul, South Korea. He is the co-editor of Neoliberalism and Global Cinema: Capital, Culture and Marxist Critique (Routledge, 2011) and China's iGeneration: Cinema and Moving Image Culture for the Twenty First Century (Bloomsbury, 2014). His forthcoming monograph entitled Living with Uncertainty: Precarious Work in Global Cinema is under contract with a major US academic press. His work has also appeared in the journals Globalizations, Race \& Class, Journal of Film and Video, Labor History, Inter-Asia Cultural Studies, Journal of History of Modern Art, Quarterly Review of Film and Video, Third Text, among others.

In-gyoo Jang is an Associate Professor of Animation Studies at Hongik University in Seoul, South Korea. He is trained as a professional animator who had worked previously at Dreamworks in Los Angeles before enter- ing academia. He holds an MFA in Animation from UCLA and is currently directing a feature-length 3-D computer-animated film being produced in both Seoul and Los Angeles. 